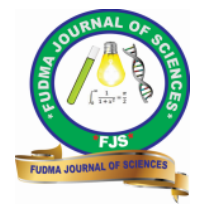

FUDMA Journal of Sciences (FJS)

ISSN online: $2616-1370$

ISSN print: 2645 - 2944

Vol. 4 No. 3, September, 2020, pp $275-284$

DOI: https://doi.org/10.33003/fjs-2020-0403-392

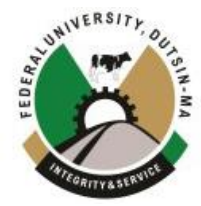

\title{
COMPARATIVE ANALYSIS OF TOTAL FACTOR PRODUCTIVITY AMONG POTATO (Solanum tuberasum) FARMERS IN BOKKOS LOCAL GOVERNMENT AREA OF PLATEAU STATE, NIGERIA.
}

\author{
${ }^{1}$ Folorunso, S. T., \& ${ }^{2}$ Bayo, D. \\ ${ }^{1}$ Department of Agricultural Economics \& Extension, University of Jos, Jos-Nigeria. \\ ${ }^{2}$ Montane Research Station, Jos, Plateau State, Nigeria.
}

Corresponding Author's email: solocom2012@gmail.com, folorunsos@unijos.edu.ng,08037018157

\begin{abstract}
This study compared Total Factor Productivity among potato farmers in Bokkos Local Government Area of Plateau State, Nigeria. A multistage sampling technique was employed to select 96 male and 64 female respondents. Data was collected from primary source through the distribution of structured questionnaire and oral interview schedule. Data collected were analyzed using descriptive statistics, net farm income and total factor productivity (TFP) models. The findings revealed that the mean age of male and female household heads was 40 and 38 years respectively, the mean household size was 5 persons for male and 4 persons for female headed households, $82.3 \%$ and 73.5 of male and female respondents were married. The mean farming experience of male and female farmers was 19 and $15 y$ years, $62 \%$ and $66 \%$ of male and female respondents did not belong to any cooperative. Potato production was profitable with NFI per hectare of male and female respondents being $\$ 473,307.65$ and $\$ 294,324.45$ respectively. The BCR was 3.15 and 5.16 for male and female respondents. Profitability Index was 0.68 and 0.81 respectively for male and female farmers. The result of probit regression revealed that the coefficients of gender, household size, farming experience and amount of credit were significant. The study recommend that: implicit sensitization of the community leaders on the active role of women in agricultural development, Policy makers at all level of government should ensure discriminatory laws or customs against women are abolished, both male and female farmers should utilize more of their household members in farming activities, farmers should be encouraged to take advantage of cooperative societies for bulk purchase of inputs and knowledge sharing on innovation.
\end{abstract}

Keywords: Comparative, Productivity, Potato, Bokkos, Plateau state.

\section{INTRODUCTION}

Agriculture by far has the widest spread of the form of human activity and it is more basic than any other industry (World Bank 2008). The World Bank (2008) also reported that before independence in 1960, agriculture was the foundation of the human economy in Nigeria and Nigeria was self-sufficient in terms of food, since about eighty percent $(80 \%)$ of our land is cultivable. The agricultural sector's contribution to the Nigeria's GDP rose from a record low $\$ 2,594,759.86 \mathrm{M}$ in 2010 to an all-time high record of $\$ 4,655,322.16 \mathrm{M}$ in 2014 (NBS, 2015). Despite this impressive contribution to the GDP growth however, increasing reduction in productivity as evidenced by productivity indices; crop yield (20\%), input use such as fertilizer $(13 \mathrm{~kg} / \mathrm{ha})$ and mechanization intensity $(10$ tractors per $100 \mathrm{ha}$ ), food insecurity and poverty has however continued to characterize Nigeria's agricultural sector and the Nigerian population thereby limiting the ability of the sector to perform its traditional role in economic development, thus resulting in dramatic increase in the incidence and severity of poverty in Nigeria (NBS, 2005 and Doreo, 2015).

Historically, the root of the crisis in the Nigerian economy lies in the neglect of agriculture and the increased dependence on a mono-cultural economy based on oil (NBS, 2005 and NBS, 2015). Agricultural and rural sectors have also suffered from neglect and underinvestment over the past two decades, while seventy-five percent $(75 \%)$ of the world's poor live in rural areas and a mere four percent $(4 \%)$ of official development assistance goes to agriculture in developing countries including Nigeria (World bank, 2008). As a result of the increasing neglect, efforts have been made over the years by the government to reducing rural poverty but unfortunately, because of the linkage between income and poverty and its effect on agricultural production, most of these efforts were abortive (Awoyemi, 2007).

Raising agricultural productivity, reducing food insecurity and poverty is an important policy goal for concerned government since agriculture plays a major role in the economy of many developing countries, as it is a significant source of nourishment for citizens and a means of livelihood for the most vulnerable members of this country Adewuyi (2002). Therefore, increasing agricultural productivity requires one or more of the following; an increase in output and input with output increasing proportionately more than inputs; an increase in output while inputs remain the same; a decrease in both inputs and output with input decreasing more; or decreasing input while output remains the same (Adewuyi, 2006; Oni et al.,2011).

Gender issues have become key in agricultural research and activities mostly focusing on the differences between sexes in production. A number of possible factors may lead to 
agricultural productivity differences between men and women in the developing world. Holding all other things constant, the quantity of inputs (e.g., fertilizer, seeds, or labor etc.) applied by men and women, the quality of inputs, land quality may differ between men and women. This also include, but not limited to, soil quality, topography and proximity to access points such as water sources, roads and housing. Men and women may have different agricultural production functions, possibly because crop choice differs by gender, whether influenced by cultural norms or by other considerations such as the lack of resources to cultivate specific crops and the culturally appropriate division of labour (Peterman et al., 2010). For instance, cultural norms attempt to deter the women fraternity involvement in very physical farming practices in Ghana, as in Ethiopia where women are forbidden from using the plough because such work is perceived to be too physically strenuous. Even if men and women have the same agricultural production function, shadow prices of inputs and credit may lead the women's production frontier to lie beneath the men's frontier, implying that women are less productive. In a review of empirical evidences and methodology in gender analysis of agricultural productivity, (Quisumbing, 2016) found that the majority of studies conducted from the mid-1980s to 1990 s showed that female farmers are equally productive as male farmers once inputs and other background characteristics are controlled.

Potato is a crop of major economic significance worldwide. This crop provides a reliable source of income, employment and food for many populations in the developing countries (FAO, 2008). Globally, potato provides food security to an estimated 800 million people (Hoffler \& Ocheng, 2009). Given the importance of Irish potato production, it is one of the realistic ventures which should be promoted not only for food security but also to ensure increased revenue for farmers. With increasing population and low output from agricultural land, adoption of improved agricultural technologies and modern method of farming is important for increased output. However, Africa is still lagging behind in terms of production and yield levels, rates of modern input uses, technology adoption, and access to credit or insurance and markets which are often failing or incomplete (Dillon \& Barrett, 2014; FAO, 2015). Among the several aforementioned constraints inhibiting maximized potato production, it is also worthy to include gender disparities in agriculture being a limiting constraint. This is justifiable because in sub-Saharan Africa, women account for almost $50 \%$ of the agricultural labor force but still suffer from low access to credit and other financial markets. Moreover, they do not have much control over their resources, have low levels of crop yields, low rates of modern input and technology adoption, and are disadvantaged in terms of human and physical capital. These gender-based differences also concern economic capacities and incentives which in turn undermine women's potential to contribute to and partake of economic growth, affect intra-household resource allocation, land productivity, and welfare levels (Kilic et al., 2013; Croppenstedt et al., 2013; Aguilar et al., 2014).
Despite the several studies conducted on productivity of potato production in Nigeria, there are limited comparative studies carried out on the study area that focuses on gender disaggregated constraints, gender imbalances, differentials in gender roles, profitability, and income equality as related to potato production.

From the foregoing therefore, the following objectives were generated to; i. Compare the socio-economic characteristics of male and female potato farmers in the study area; 2 . Compare the productivity of potato production among male and female potato farmers and iii. estimate the determinants of productivity among male and female potato farmers in the study area.

\section{MATERIALS AND METHOD}

\section{Study Area}

The study was conducted in Bokkos Local Government Area of Plateau state. The Bokkos Local Government area is located on latitude of $9000^{\circ} 20^{\prime} \mathrm{E}$ and longitude of $9018^{0} 00^{\prime} \mathrm{N}$. It has an estimated 2020 population of 272,795 (NPC, 2006) and a land area of about1.682km2 (649sq.m). Bokkos Local Government Area is in the central zone of plateau state, Nigeria and it is one of the 17 LGAs in the state. It was created in 1991 out of the Mangu Local Government Area of Plateau State. Its headquarters is Bokkos which is 77 kilometers from Jos the state capital. The L.G.A shares boundaries with Qua'an Pan L.G.A to the south, Barkin-Ladi to the North. Sanga L.G.A of Kaduna state and Wamba L.G.A of Nasarawa state to the West and Mangu LGA to the East. Bokkos local government has eight districts namely; Sha, Manguna, kwatas, Daffo, Kulere, Mushere, Bokkos and Toff. Though situated in the tropical zone, a higher altitude means that the local Government Area has a temperate climate with an average temperate of between $18^{\circ} \mathrm{C}$ and $22^{\circ} \mathrm{C}$. Harmattan winds cause the coldest weather between December and February. The warmest temperature usually occurs in the dry season months of March and April. The mean annual rainfall is $146 \mathrm{~cm}$ (57inches). the highest rainfall is recorded during the wet season months of July and August. Bokkos, the LGA capital is a semi-urban settlement and is the biggest while other settlements are rural. People live largely in lowland areas in dispersed settlements and compounds usually unfenced. The crops cultivated in the area are yam, maize, potato, sugarcane, cocoa yam while the livestock reared in the area are goats, sheep, pigs and cattle. Languages spoken are mostly, Ron, Mushere and kulere. their occupation is mostly farming and local tin mining.

\section{Sampling Technique and Sampling Size}

Multistage sampling techniques was used for the study. This involved a purposive selection of 4 districts out of 8 districts. The second - stage involved a random selection of 2 villages from each of the 4 districts selected. Finally, 10\% of the sample frame was randomly selected from each of the selected villages in the study areas. Therefore, 160 (96 males and 64 females) potato farmers will constituted the sampling size that will be used for the study. 
Table 1: Sample distribution of potato farmers in Bokkos Local Government Area.

\begin{tabular}{llllll}
\hline DISTRICTS & VILLAGES & $\begin{array}{l}\text { MALE } \\
\text { SAMPLE }\end{array}$ & $\begin{array}{l}\text { MALE } \\
\text { SAMPLE }\end{array}$ & $\begin{array}{l}\text { FEMALE } \\
\text { SAMPLE }\end{array}$ & $\begin{array}{l}\text { FEMALE } \\
\text { SAMPLE } \\
\text { SIZE (10\%) }\end{array}$ \\
\hline \multirow{2}{*}{ Daffo } & & 106 & 9 & 80 & 8 \\
& Hottom & 60 & 6 & 50 & 5 \\
Mushere & Maiduna & 89 & 12 & 72 & 7 \\
& Kawel & 120 & 23 & 38 & 3 \\
Bokkos & Garah & 233 & 38 & 200 & 20 \\
& Marish & 380 & $\mathbf{9 6}$ & 217 & 21 \\
& Kwatas & $\mathbf{9 8 8}$ & $\mathbf{6 5 7}$ & $\mathbf{6 4}$ \\
\hline
\end{tabular}

Source: Field survey, 2019.

\section{Method of Data Collection}

Primary data was collected for the study using wellstructured questionnaire and interview schedule that were administered to the selected potato male and female potato farmers. The information generated includes socio-economic characteristics of potato farmers (age, gender, educational background, household size, farm size, potato farming experience, production system practiced, membership of association, source of capital), the inputs used (seed potato, fertilizer, agrochemicals, labour, etc. ), and the costs and income from sale of potato (the quantity harvested potato sold).

\section{Analytical Technique}

The following tools of analysis were employed to achieve the objectives of the study; Descriptive statistics, Farm Budget technique (Net Farm Income Analysis), Total Factor Productivity Index, Multiple Regression Model and Gini coefficient were used to achieve the objectives of the study.

\section{Descriptive Statistics}

This involved the use of tables, charts, measures of central tendency such as mean, median, frequency distribution. It was used to achieve objective i.

\section{Farm Budget Technique}

Farm budgeting technique was employed to estimate the Net Farm Income of potato production as stated in objective (ii). The farm budgeting model used by Yusuf et al. (2008) and Adewumi (2017) was adopted and specified in equation (1) as:

$N F I=\sum_{i=1}^{n} P_{i} Y_{i}-\sum_{j=1}^{m} P_{j} X_{j}-\sum_{k=1}^{o} F_{k}$

Where;

$N F I=$ Net farm income

$Y_{i}=$ quantity potato output $(\mathrm{kg})$

$P_{i}=$ Unit price of potato $(\$)$

$X_{j}=$ Quantity of the variable inputs used per Ha (where $j=$, $1,2,3, \ldots, m$ variable inputs)

$P_{j}=$ Price per unit of variable inputs.

$F_{k}=$ Cost of fixed inputs per Ha (where $k=, 1,2,3, \ldots, o$ fixed inputs.

The items that make up the variable items $X_{j}$ are; seed potato $(\mathrm{Kg} / \mathrm{Ha})$, Agrochemicals (Litre/Ha), fertilizer ( $\mathrm{kg} / \mathrm{Ha})$, family labour (manday), hired labour (Manday) and cost of land rent $(\mathrm{A} / \mathrm{Ha})$. In other to obtain the fixed costs $\left(F_{k}\right)$ of the items such as the Knapsack sprayer, Hoes, cutlasses, wheel barrows, etc. were depreciated to obtain proportion of these items consumed during one year. The straight-line method was used for this purpose.

The following profitability measures were also calculated;

$\mathrm{PI}=\frac{N F I}{T R}$

$\mathrm{BCR}=\frac{\sum_{i=0}^{n} \text { Benefit }}{\sum_{i=0}^{n} \operatorname{Cost}}$

NFI= Net Farm Income per unit of Total Revenue

$\mathrm{TR}=\sum_{i=0}^{n} P_{i} X_{i}$

$\mathrm{RRI}=\frac{N F I}{T C}=\frac{N F I}{\sum_{j=1}^{m} P_{i} X_{j}+\sum_{k=1}^{0} F_{k}}$

$\mathrm{TC}=$ Total Cost $=\sum_{j=1}^{n} P_{i} X_{j}+\sum_{i=0}^{n} F_{k}$

Annual Depreciation $=\frac{\text { Asset cost }- \text { Salvage value }}{\text { Useful Life of asset }(\text { years })}$

Depreciable amount equals cost minus salvage values. Cost is the amount at which the fixed asset is capitalized. Salvage value (also called residual or scrap value) is the estimated value of the fixed asset at the end of its useful life. Useful life of a fixed asset represents the number of accounting periods within which the asset is expected to generate economic benefits. It was used to achieve part of objective ii.

Total Factor Productivity

Total factor productivity (TFP) is a method of calculating agricultural productivity by comparing an index of agricultural inputs to an index of outputs (Jean-Paul, 2009). This can be computed following Key \& McBridge (2005) as the output ratio of the output to the total variable cost (TVC):

$\frac{\mathrm{TFP}}{\mathrm{TVC}}=\frac{Y}{T V C}=\frac{Y}{\sum P i X i}$

Where: $\mathrm{Y}=$ quantity of output, $\mathrm{TVC}=$ total variable cost, $\mathrm{P} i$ $=$ unit price of the $\mathrm{i}^{\text {th }}$ variable input, and $\mathrm{X}_{i}=$ quantity of $\mathrm{i}^{\text {th }}$ variable input. This methodology ignores the role of total fixed cost (TFC) as it does not affect either the profit maximization or the resource-use efficiency conditions (Fakayode et al., 2008) Therefore, equation 3 can be rewritten as; 
$\mathrm{TFP}=\frac{Y}{A V C}$

The interpretation of TFP index are as follows;

$\begin{array}{ll}\frac{\text { Index }}{(<0.1)} & \frac{\text { Interpretation }}{\text { Sub-optimal }} \\ (1.0-1.09) & \text { Optimal } \\ (\geq 1.10) & \text { Super-optimal }\end{array}$

This was also used to achieve part of objective ii

Following Feder et al (1990) the production behaviour of the two groups of farmers is modeled by reduced form equations specified by in the probit model as:

$Y_{1 j}=B_{1}^{\prime} X_{1 j}+U_{j}$ if $\mathrm{J}=1$

$Y_{1 j}=B_{2}^{\prime} X_{2 j}+U_{2 j}$ if $\mathrm{J}=0$

$\mathrm{X}_{1}=$ Age (Years)

$\mathrm{X}_{2}=$ Gender $(1=$ male, female $=0)$

$\mathrm{X}_{3}=$ Education (Years)

$\mathrm{X}_{4}=$ Household size (Number of persons)

$\mathrm{X}_{5}=$ Years of farming experience (Years)

$\mathrm{X}_{6}=$ Years of cooperative membership (years)

$\mathrm{X}_{7}=$ Volume of loan obtained (

$X_{1 j}$ and $X_{2 j}$ are vectors of exogenous variables, $B_{1 j}$ and $B_{2 j}$ are vectors of parameters and $\mathrm{u}_{1 \mathrm{j}}$ and $\mathrm{U}_{2 \mathrm{j}}$ are random disturbance terms. $Y_{1 j}$ and $Y_{2 j}$ represent the productivity indices of male headed and female households of potato farmers respectively. This was used to achieve objective iii.

\section{RESULTS AND DISCUSSION}

\section{Socio-economic Characteristics of Respondents}

The result of the study shows the that minimum age of the farmers cultivating potato in the study was made up of 22 years and 20 years, maximum age was 62 years and 70 years and the mean age are 40 years and 38 years for male and female potato farmers respectively. The potato farmers in the study area are within the age bracket of $20-50$ years for both male and female farmers. The increasing age of potato farmers would lead to low productivity because the ageing farmers are less energetic to work (Kuye, 2015 and Ogundari et al. (2006).

The result further shows that $82 \%$ and $74 \%$ of the male and female potato farmers respectively were married while $15 \%$ and $25 \%$ of the male and female farmers respectively were singles. This indicate that there are more married male potato farmers than the female potato farmers in the study area while there were less singles male potato farmers than the females. In their study of gender differentials in technical efficiency among maize farmers in Essien Udim Local Government Area-

Nigeria, Simonyan \& Omolehin (2012) observed that marital status was positive and significantly related to the productivity of the male farmers. The result is also in consonance with the findings of Oderhohow (2008) and Ojo \& Jibowo (2008), who reported that married people were responsible and their views are likely to be respected within rural communities as they take decision on the use of agricultural inputs. The results in Table 2 also shows that $87 \%$ and $84 \%$ of male and female potato farmers had one form of education or the other. In addition, the male potato farmers spent minimum of 16 years on formal education while the female potato farmers spent minimum of 12 years. This means that marginally, the male potato farmers were more educated than the female farmers. African Development Bank (AfDB) (2014) and Anyanwu (2016) have all shown that the female gender was disadvantaged educationally compared to the males. Nwaru (2007) in his study also isolated illiteracy as a key hindrance to institutional support towards agriculture. Also, Amos (2007) and Nyagaka et al. (2010) revealed that education had positive relationship with efficiency.

The result of farming experience shows that the mean farming experience of the male potato farmers was 19 years while that of the female potato farmers was 15 years. By implication, potato farmers in the study area have fairly large farming experience, however, the male respondents have more experience and would likely handle production uncertainties better than the female respondents. This is in line with Jesse et al., (2018) who reported that farmers have high level of experience in potato farming, which suggest their managerial ability in terms of managing uncertainties such as pest and diseases. Experience influence individual farmer perception and understanding of improved farm production (FAO, 2008). In the study of resource use efficiency and multiple production objectives of pastoralists dairy in Adamawa state, Adebayo (2006) observed that the longer a person stays on a particular job, the better the job performance tends to be.

From table 2, the mean household size of male and female headed households was 5 and 4 persons respectively. This implies that family labour may not be readily available, since both genders had relatively small household sizes. Invariably, this might increase labour cost incurred as farmers will likely use hired labour. According to OkoedoOkojie \& Onemolease, (2009), household size influences the availability of family labour for agricultural operations, since the main source of labour for a typical traditional farmer is his or her immediate dependents.

Result in table 2 indicate that $78 \%$ and $77 \%$ of male and female respondents engage in faming while the remaining respondents engaged themselves in other livelihood activities such as trading, civil service and marketing. This means that farming is the predominant occupation of the respondents in the study area. Jatbong et al. (2018) in their study on gender differential in production input used and profitability in Irish potato production in Plateau State, Nigeria noted that men and women produce potato to reduce unemployment, improve productivity among rural dwellers.

The result on table 2 shows that $62 \%$ and $66 \%$ of male and female potato farmers were not involved in cooperative activities while $38 \%$ and $34 \%$ of the male and female respondents had varying years of involvement in cooperative societies. The result indicates that farmers had less access to resources and information that could improve their production practices. Folorunso, et al.2018, Ekong (2003) and Ajayi \& Ogunlola (2005), all observed that membership of cooperative societies has advantages of accessibility to micro-credit and input subsidy, serve as an avenue of knowledge and information sharing, source of 
pooling resources together for bulk purchases of inputs and avenue to access inputs at subsidize rates.

The result of the table 2 further reveals that the mean annual credit accessible by both male and female respondents was $\$ 81,914$ and $\$ 28,984$ respectively. The implication is that farm size expansion will be limited. Limited access to credit services have been reported in many parts of Sub-Saharan
Africa as well as other developing countries as the limiting factor for increased agricultural production and productivity (Eze et al., 2006; Junge et al., 2009; Okoedo-Okojie \& Onemolease, 2009). Ekong (2003), also asserted that credit is a very strong factor that is needed to acquire or develop any enterprise; its availability could determine the extent of production capacity.

Table 2: Socioeconomic characteristics of potato farming households

Male Headed

Female Headed

\begin{tabular}{|c|c|c|c|c|}
\hline Characteristics & Frequency & Percentage & $\overline{\text { Frequency }}$ & Percentage \\
\hline \multicolumn{5}{|l|}{ Age } \\
\hline$<30$ & 7 & 7 & 4 & 6 \\
\hline $31-40$ & 25 & 26 & 23 & 36 \\
\hline $41-50$ & 37 & 39 & 25 & 39 \\
\hline $51-60$ & 23 & 24 & 9 & 14 \\
\hline Above 60 & 4 & 4 & 3 & 5 \\
\hline Total & 96 & 100 & 64 & 100 \\
\hline \multicolumn{5}{|l|}{ Mean } \\
\hline & 40 & & 38 & \\
\hline \multicolumn{5}{|l|}{ Marital Status } \\
\hline Single & 15 & 15 & 16 & 25 \\
\hline Married & 78 & 82 & 46 & 73 \\
\hline Divorced & 01 & 01 & 02 & 02 \\
\hline Widowed & 02 & 02 & - & - \\
\hline Total & 96 & 100 & 64 & 100 \\
\hline \multicolumn{5}{|c|}{ Educational status } \\
\hline Non-formal & 12 & 13 & 10 & 16 \\
\hline Primary & 26 & 27 & 28 & 44 \\
\hline Secondary & 57 & 53 & 15 & 23 \\
\hline Tertiary & 07 & 07 & 11 & 17 \\
\hline Total & 96 & 100 & 64 & 100 \\
\hline \multicolumn{5}{|c|}{ Farming Experience } \\
\hline $1-5$ & 05 & 05 & 11 & 17 \\
\hline $6-10$ & 17 & 18 & 17 & 27 \\
\hline $11-15$ & 23 & 24 & 09 & 14 \\
\hline $16-20$ & 17 & 18 & 08 & 12 \\
\hline Above 20 & 34 & 35 & 19 & 30 \\
\hline Total & 96 & 100 & 64 & 100 \\
\hline \multicolumn{5}{|l|}{ Mean } \\
\hline & 19 & & 15 & \\
\hline \multicolumn{5}{|l|}{ Farm size } \\
\hline$\leq 2$ & 46 & 48 & 34 & 53 \\
\hline $2.1-4.9$ & 38 & 40 & 26 & 41 \\
\hline$\geq 5$ & 12 & 12 & 4 & 6 \\
\hline Total & 96 & 100 & 64 & 100 \\
\hline Mean & 3.1 & & 2.5 & \\
\hline \multicolumn{5}{|l|}{ Household size } \\
\hline$\leq 2$ & 46 & 48 & 41 & 64 \\
\hline $6-10$ & 43 & 45 & 23 & 36 \\
\hline $11-15$ & 6 & 6 & - & - \\
\hline$\geq 16$ & 1 & 1 & - & - \\
\hline Total & 96 & 100 & 64 & 100 \\
\hline Mean & 5 & & 4 & \\
\hline Occupation & 75 & 78 & 49 & 77 \\
\hline Farming & 1 & 1 & 8 & 12 \\
\hline Civil service & 1 & 1 & 3 & 5 \\
\hline Trading & 15 & 16 & 2 & 3 \\
\hline Marketing & 4 & 4 & 2 & 3 \\
\hline Total & 96 & 100 & 64 & 100 \\
\hline
\end{tabular}




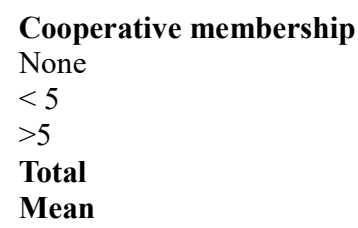

Loan Acquisition

$<50,000$

$50,001-100,000$

$>100,000$

Total

Mean

Source: Field survey, 2019.

\section{Productivity of Potato Production}

Results presented in table 3 shows that the Total Revenue (TR) was $\$ 693,603.41$ and $\$ 365,085.64$ per hectare for male and female potato farmers respectively, the Total Variable Cost (TVC) was $\$ 174,249.12$ and $\mathrm{N} 62,309.21$ per hectare for male and female respectively while the Total Cost (TC) was $\mathrm{N} 220,295.76$ and $\mathbf{N} 70,761.19$ per hectare for male and female respectively. The net farm income per hectare for male and female respondents was N473,307.65 and \#294,324.45 respectively. The BCR was 3.15 and 5.16 for male and female potato farmers respectively; the P.I was 0.68 and 0.81 for male and female potato farmers respectively,

\begin{tabular}{llll}
59 & 62 & 12 & 66 \\
22 & 23 & 16 & 25 \\
15 & 5 & 6 & 9 \\
$\mathbf{9 6}$ & $\mathbf{1 0 0}$ & $\mathbf{6 4}$ & $\mathbf{1 0 0}$ \\
$\mathbf{1}$ & & & \\
& & $\mathbf{0 . 4}$ & \\
11 & 32 & 7 & 42 \\
5 & 15 & 5 & 29 \\
18 & 53 & 5 & 29 \\
$\mathbf{9 6}$ & $\mathbf{1 0 0}$ & $\mathbf{6 4}$ & $\mathbf{1 0 0}$ \\
$\mathbf{8 1 , 9 1 4 . 9 8}$ & & $\mathbf{2 8 , 9 8 4 . 4 2}$ & \\
\hline
\end{tabular}

the RRI was 2.15 and 4.16 for male and female potato farmers respectively. The result further shows that the TR, TVC and TC of the male potato farmer were higher than the female potato farmers. OECD, (2011) stated that productivity differential between men and women averages around 20-30 per cent due to differences in resource availability and use. However, the various profitability measures revealed that, that of the female potato farmers were higher than that of the female potato farmers. This means that the female potato farmers were more efficient and productive in resource use in the study area.

Table 3: Estimates of profitability of potato production among male and female farmers.

\begin{tabular}{|c|c|c|c|}
\hline \multirow[t]{2}{*}{ Item/ Ha } & \multicolumn{2}{|l|}{ Value/Ha } & \multirow[t]{2}{*}{ a } \\
\hline & Male & Female & \\
\hline Total Revenue & $693,603.41$ & $365,085.64$ & \\
\hline Labour & $13,741.29$ & $8,615.98$ & \\
\hline Agrochemicals & $57,843.14$ & $1,284.79$ & \\
\hline Fertilizer & $22,235.43$. & $10,979.42$ & \\
\hline Manure & $8,843.55$ & $4,668.25$ & \\
\hline Seeds & $49,523.45$ & $14,461.47$ & \\
\hline Land rent & $22,062.26$ & 22,300 & \\
\hline Total Variable Cost & $174,249.12$ & $62,309.21$ & \\
\hline Depreciation (TFC) & $46,046.64$. & $8,452.98$ & \\
\hline Total Cost & $220,295.76$. & $70,761.19$ & \\
\hline Net Farm Income & $473,307.65$. & $294,324.45$ & \\
\hline Benefit Cost Ratio (BCR) & 3.15 & 5.16 & \\
\hline Profitability index (PI) & 0.68 & 0.81 & \\
\hline Return on investment (ROI) & 2.15 & 4.16 & \\
\hline
\end{tabular}

Source: Field survey, 2019. 
Total Factor Productivity of Potato Production

The summary statistics of the TFP result in table 4 shows that $98 \%$ male and $100 \%$ female potato farmers were superoptimally productive as their TFP indices were above the optimal scale, which indicated super-optimal input mix allocation in the production process. Only $1 \%$ of the male farmers were found not to be productive as their TFP indices was below the optimal scale $(<1)$ and $1 \%$ also hovered around the optimal scale $(1.0-$ 1.09). On the other hand, none of the female farmers were either less productive or hovered around the optimal scale, rather, the respondents were all in the super-optimal category $(>1.1)$ in their production processes. By implication, female farmers tend to be more productive than the male counterparts, having the highest percentage of women with TFP greater than optimal. The high productivity could be attributed to the super-efficient ways both the male and female potato farmers utilize their input mix, which yielded high potato output in their respective farms in the study area.

Table 4: Distribution of respondents according to total factor productivity (TFP)

\begin{tabular}{|c|c|c|c|c|}
\hline & Male & & Fema & \\
\hline Variable & Freq & $\%$ & Freq & $\%$ \\
\hline Sub-optima $(<1.00)$ & 1 & 1.10 & 0 & 0 \\
\hline Optima (1.00 - 1.09) & 1 & 1 & 0 & 0 \\
\hline Super-optima $(>1.10)$ & 92 & 97.90 & 64 & 100 \\
\hline Total & 94 & 100 & 64 & 100 \\
\hline Mean & 13.64 & & 15.42 & \\
\hline
\end{tabular}

Source: Field survey, 2019.

\section{Hypothesis Testing}

Table 5 shows mean productivity of 0.014 and 0.011 for the male and female farmers respectively. The $\mathrm{Z}$ test conducted revealed that there is significant difference at $10 \%$ level of probability in the Total Productive Factor (TFP) between the means of the two groups of respondents, which is the male (13.64) and female (15.42) respondents. This test further proves female dominance with respect to TFP over the male counterparts, since the female tend to have significant higher mean score and percentage than the male potato farmers in the study area. In other words, the $\mathrm{Z}$ test implied that, female potato farmers are better off than the male farmers in the management and effective utilization of the available input resources at their disposal during production processes. According to Adamon \& Adeleke (2015) in their study on gender productivity differentials among smallholder farmers in Africa: A cross-country comparison, concluded generally from the literature they reviewed that female farmers are at least as efficient as their male counterparts and therefore there exist considerable potential gains from closing or at least reducing the gender productivity gap.

Table 5: Estimation of Z-test of total factor productivity

\begin{tabular}{lll}
\hline Variable & Female & Male \\
\hline Mean & 13.58915 & 15.39545 \\
Known Variance & 119.04 & 299.78 \\
Observations & 63 & 92 \\
Hypothesized Mean Difference & 0 & \\
$\mathrm{P}(\mathrm{Z}<=\mathrm{z})$ one-tail & 0.212986 & \\
$\mathrm{z}$ Critical one-tail & $1.644854^{*}$ & \\
$\mathrm{P}(\mathrm{Z}<=\mathrm{z})$ two-tail & 0.425972 & \\
$\mathrm{z}$ Critical two-tail & $1.959964^{*}$ & \\
\hline
\end{tabular}

Source: Field survey, 2019.

\section{Determinants of total factor productivity}

Probit regression model was used to identify factors influencing credit constraint condition of farmers. Table 6 shows the maximum likelihood estimates of the probit model. In the model, coefficients of four out of seven explanatory variables were significant. It is evident from the table that the gender of farmers, household size of farmers, years of farming experience, and amount of loan were significant variables that influence total factor productivity in 
the study area. The marginal effects were indicators of one unit change in an exogenous variable on the probability that a farmer was productive. The result in table 6 revealed a chisquare value of 12.01 , which was significant at $1 \%$ level $(p<0.01)$. This implies that the model (regression line) fits the data reasonably. The Pseudo $\mathrm{R}^{2}$ was 0.16 and the loglikelihood was -108.09 , which suggests strong explanatory power of the model for the sampled population, i.e. both the male and female headed households. This also indicates that variation in total factor productivity was explained by the (maximum likelihood) estimates of the specified explanatory variables, suggesting that the model as specified, explained significant non-zero variations in the determinants total factor productivity (TFP) among the potato farming households in the study area. The results further revealed that gender, household size, years of experience and amount of loan collected among other variables regressed were the determinants of total factor productivity among potato farmers in the study area.

Gender had a positive coefficient (6183.79) and was statistically significant at $1 \%$ level of probability. This indicate a positive relationship with total factor productivity which implies that, increase in number of male farmers by $1 \%$ will likely increase its TFP by $19 \%$. This result is in line with the findings of Ukoha et al. (2010) in their study on the analysis of the determinants of total factor productivity among small-holder cassava farmers in Ohafia L.G.A of Abia State, in which they reported positive relationship of gender with TFP.

The estimated coefficient of household size was positive (3512.37) and was significant at 5\% probability level, meaning that farmers with large household size had the tendency of being more productivity when compared to their counterparts with small family holdings. The marginal implication of increase in farm household size would lead to increase in TFP by $35 \%$.
This could be attributed to farming household being dominated by strong and capable people thereby rendering their effects with respect to farm labour provision felt in potato production. This finding contradicts the results of Okoye et al., (2008) in their analysis of the determinants of labour productivity on small-holder cocoyam farms in Anambra and also the findings of Ukoha et al. (2010) as they reported a negative influence of household size on TFP.

The coefficient for years of farming experience among the respondents was positive and significant at $10 \%$ level of probability. This implies that for every $1 \%$ increase in farming experience decreases the tendency of being productive in the production processes by $30 \%$. This could be attributed to old age of the respondents as experience comes with increase in age and farmers may reduce in strength and agility as they age. This may, more often than not, likely reduce their productivity, especially when it is labour productivity. This reasoning is in line with Ukoha et al., (2010), as he reported that old age might pose a disadvantage to agriculture. The result also showed the coefficient of amount of loan was positive (1488.67) and highly significant at $1 \%$ level of probability. This suggests that farmers with access to appreciable amount of loan would likely be more productive than potato farmers with little or no loan. That is, increase of amount of loan by $1 \%$ will increase the TFP of the respondents by $6 \%$. This increment in productivity could be attributed to increase in the operational capacities of the potato farmers by virtue of the amount of loan collected; this is in conformity with the assumption that large-sca8le enterprise if effectively managed benefit from economies of scale, specialization and other pecuniary advantages (Sadiq et al., 2018).

Table 6: Estimation of the determinants of total factor productivity

\begin{tabular}{|c|c|c|c|c|}
\hline Variables & Coefficient & Standard Error & T-value & Marginal effect \\
\hline Constant & 5057.959 & 3099.601 & 1.63181 & \\
\hline Age & 1987.71 & 1296.84 & 1.532734 & 0.12968 \\
\hline Gender & $6183.785^{* * *}$ & 1885.995 & 3.278792 & 0.18860 \\
\hline Education & 1330.811 & -889.5274 & -1.49609 & -0.08895 \\
\hline Household size & $3512.365 * *$ & 1564.528 & 2.245 & 0.35124 \\
\hline Years of experience & $-2990.856^{*}$ & 1518.502 & -1.96961 & -0.29909 \\
\hline Years of membership & 1703.457 & -1407.981 & -1.20986 & -0.04080 \\
\hline Amount of loan & $1488.621 * * *$ & 594.2809 & 2.504911 & 0.05943 \\
\hline Log likelihood & -108.0908 & & & \\
\hline Prob $>\mathrm{chi}^{2}$ & 0.001 & & & \\
\hline Pseudo $\mathrm{R}^{2}$ & 0.159 & & & \\
\hline $\operatorname{LR} \operatorname{chi}^{2}(7)$ & 12.01 & & & \\
\hline
\end{tabular}

Note $^{* * *}, * *$ and $*$ Significant at $1 \%, 5 \%$ and $10 \%$ levels of probability.

\section{SUMMARY, RECOMMENDATIONS \\ CONCLUSION}

AND

The study examined comparative total factor productivity of potato farming households in Bokkos Local government area of Plateau state, Nigeria. The farming population was economically virile and literate, possessed average household sizes and most of the farms they operated on were their personal assets. The enterprise was found to be profitable and significantly different both for the male and female farmers in the study area. The study further revealed that there is significant difference in the Total Productive Factor (TFP) 
between the means of the two groups of respondents. Based on the above scenario, the following recommendations were made: implicit sensitization of the community leaders on the active role of women in agricultural enhancement and the successes so far recorded in other parts of the country should be a reference so that more women in the study area will be able to participate in farm enterprise, thus, easing them out of the vicious cycle of poverty and thus contributing meaningfully to food security, Policy makers at all level of government should ensure discriminatory laws or customs against women are abolished in order to further stimulate active participation of women in agriculture, both male and female farmers should utilize more of their household members in farming activities in order to reduce cost of labour in potato production, farmers should be encouraged further to take advantage of cooperative societies for bulk purchase of inputs and knowledge sharing on innovation.

\section{REFERENCES}

Adamon, N. M. \& Adeleke O. S (2015). Gender Productivity Differentials Among Smallholder Farmers in Africa: A Cross-Country Comparison Gender Productivity Differentials Among Smallholder Farmers in Africa: A CrossCountry Comparison. Working Paper Series. No. 231, African Development Bank.

Adewuyi, S. A. (2002) "Resource Use Productivity in Food Crop Production in Kwara State, Nigeria. "Unpublished Ph.D. Thesis Department of Agricultural Economics University of Ibadan, Ibadan.

Adewuyi, S.A (2006) "Resource Use Productivity of Rural Farmers in Kwara State, Nigeria." International Journal of Agricultural Sciences, Sciences, Environment and Technology 1(1) 44 - 50 .

Aguilar, A., Carranza, E., Goldstein, M., Kilic, T. \& Oseni, G. (2014). Decomposition of Gender Differentials in Agricultural Productivity in Ethiopia. Policy Research Working Paper, No.6764, The World Bank.

Adebayo, E.F. (2006). Resource Use Efficiency and Multiple Production Objectives of Dairy Pastoralists in Adamawa state, Nigeria. Unpublished $\mathrm{PhD}$ thesis, University of Ibadan.

Ajayi, M. T. \& Ogunlola, J. O. (2005). Farmers Perceived Extension Practices in Akure Area of Ondo State, Nigeria. Nigeria Global Approaches to Extension. 29 (1): 1-8. African Development Bank (AfDB) (2014), AfDB Gender Strategy (2014-2018), AfDB, Tunis.

Amos, T. T. (2007). An Analysis of Productivity and Technical Efficiency of Smallholder Cocoa Farmers in Nigeria', Journal of Social Science. Vol. 15, No. 2, pp. 127-33.

Anyanwu, J. C. (2016). 'Accounting for Gender Equality in Secondary School Enrolment in Africa', African Development Review, Vol. 28, No. 2, pp. 170-91.

Awoyemi, T.T. \& Adeoti, I.A. (2006). Gender Inequalities and Economic Growth: New Evidence from Cassava-Based Farm Holdings in Rural South-Western Nigeria. Journal compilation of African Development Bank. Published by Blackwell Publishing Ltd 9600 Garsington Road, Oxford OX4 2DQ, UK and 350 Main Street, Malden, MA 02148, USA. Pp. 428442 .

Croppenstedt, A., Goldstein, M. \& Rosas, N. (2013). Gender and Agriculture: Inefficiencies, Segregation, and Low Productivity Traps. Policy Research Working Paper, No.6370, The World Bank.

Doreo Partners (2015). Review of Nigerian Agricultural Productivity. Down loaded from http://www.doreopartners.com/review-low-agriculturalproductivity-in-nigeria. Date: 10th January, 2015.

Dillon, B. \& Barrett, C.B. (2014). Agricultural Factor Markets in Sub-Saharan Africa: An Updated View with Formal Tests for Market Failure. Policy Research Working Paper. No.7117.

Ekong E. E. (2003). Rural Sociology: An Introduction and Analysis of Rural Nigeria. Dove Educational Publication, Uyo. Eze, C. C., Ibekwe, U. C., Onoh, P. O. \& Nwajiuba, C. U. (2006). Determinants of Adoption of Improved Cassava Production Technologies among Farmers in Enugu State of Nigeria. Global Approaches to Extension Practice. 2 (1): $37-$ 44.

Fakayode, B.S., Omotesho, O.A, Tsoho, A.B. \& Ajayi, P.D. (2008): An Economic Survey of Rural Infrastructures and Agricultural Productivity Profiles in Nigeria. European Journal of Social Sciences. 7(2):158-171.

Food and Agricultural Organization (2008). Potato world production and consumption. [http://faostat.fao.org/default.aspx] site visited on 24/11/2019. FAO (2015). The State of food insecurity in the world. Retrieved from http://www.fao.org/3/a-i4646e.pdf. Accessed: November 21, 2019.

Folorunso, S.T., Gama, E.N. \& Binugo, (2018). Impact Analysis of Irish Potato Blight (phytopthora infestans) on Food Security among Farmers in Bokkos Local Government Area of Plateau State, Nigeria. Journal of Agricultural Economic Extension and Social Sciences. Volume 1 number 1, (I). Pp 57-58.

Hoffler, H. and Ochieng, B. O. (2009). High Commodity Prices-Who Gets the Money? A Case Study on the Impact of High Food and Factor Prices on Kenyan Farmers. Heinrich Boll Foundation, Berlin, Germany.

Jatbong, J.N., Sani, R.M., Salawu, J.A. \& Suleiman, H.R. (2018). Gender Differential in Production Input used and Profitability in Irish Potato Production in Plateau State, Nigeria. Direct research Journal of Agriculture and Food Science. Vol. 6 (12), pp.394-403.

Jesse B, Vihi S.K Dalla AA, Emefiene M.E \& Kwembeh T.T (2018) Gender differential in technical efficiency among maize farmers in Mangu Local Government of Plateau State, Nigeria. Journal of Agricultural Economic Extension and 
Social Sciences Vol 1 Nol may, (2018).

Junge, B., Deji, O., Abaidoo, R., Chikoye, D. \& Stahr, K. (2009). Farmers' Adoption of Soil Conservation Technologies: A Case Study from Osun State, Nigeria. Journal of Agricultural Education and Extension, 15 (3): 257- 274 .

Key, N. \& McBride, W. (2003): Production Contracts and Productivity in the U.S. Hog Sector. American Journal of Agricultural Economics. 85(1):121-133.

Kilic, T., Palacios-Lopez, A. \& Goldstein, M. (2013). Caught in a Productivity Trap: A Distributional Perspective on Gender Differences in Malawian Agriculture. Policy Research Working Paper, No. 6381, The World Bank.

Kuye, O.O. (2015). Comparative Analysis of Constraints to Cassava Production by Cassava Farmer Loan Beneficiaries and Loan Non-Beneficiaries in South-South Nigeria. Global Journal of Agricultural Research. Vol.3, No.3, pp.38-52.

National Bureau of Statistics (NBS) (2015). Nigeria Poverty Assessment report. National Bureau of Statistics, Abuja: 1520.

National Bureau of Statistics (NBS) (2005). Nigeria Poverty Assessment (harmonized). National Bureau of Statistics, Abuja.

National Population Commission (2006). National Population Commission. Population Census of the Federal Republic of Nigeria. Census Report. National Population Commission, Abuja.

Nwaru, J. C. (2007). Gender and Relative Technical Efficiency in Smallholder Arable Crop Production in Abia State of Nigeria. International Journal of Agriculture and Rural Development. Vol. 10, No. 2, pp. 25-34.

Nyagaka, D. O., Obare, G. A., Omiti, J. M. \& Nguyo, W. (2010). Technical Efficiency in Resource Use: Evidence from Smallholder Irish Potato farmers in Nyandarua North District, Kenya', African Journal of Agricultural Research. Vol. 5, No. 11. Pp. 1179-86.

Oderhohow, E. (2008). Beef Marketing in Ugheli North Local Government Area of Delta State. Unpublished B.Agric Project submitted to the Department of Agricultural Economic and Extension, Delta State Univeristy, Abraka, Nigeria. pp 48.

Ojo, M.A. \& Jibowo, A. A. (2008). Socio-Economic Characteristics Influencing Role Performance of Rural Community Power Actors in Agricultural Extension Delivery System in Osun State, Nigeria: Journal of Agriculture and Rural Development. 2:27-40.

Okoedo-Okojie, D. U. \& Onemolease, E. A. (2009). Factors Affecting the Adoption of Yam Storage Technologies in the
Northern Ecological Zone of Edo State, Nigeria. Journal of Human Ecology. 27(2): 155-160.

Okoye, B.C., C. E., Onyenweaku, O. O., Ukoha, G. N. Asumugha \& Aniedu, O.C. (2008). Determinants of Labour Productivity on Small-Holder Cocoyam farms in Anambra State, Nigeria. Academic Journals Scientific Research and Essay. Vol 3(11): 559-561.

Oni, O. A., K. K., Salman and B.O Idowu (2011). 'Social Capital Dimension and Food Security of Farming Households in Ogun State, Nigeria'Journal of American Science, 7(8):776 - 783. Organization for Economic Cooperation and Development (OECD) (2011), Fostering Productivity and Competitiveness in Agriculture, OECD, Paris.

Peterman, A., Behrman, J. \& Quisumbing, A. R. (2010). A Review of Empirical Evidence on Gender Differences in Nonland Agricultural Inputs, Technology, and Services in Developing Countries. IFPRI Discussion Paper 00975. Poverty, Health, and Nutrition Division (PHND). Washington, D.C.: International Food Policy Research Institute.

Quisumbing, A. R. \& Pandolfelli, L. (2010). Promising Approaches to Address the Needs of Poor Female Farmers: Resources, Constraints, and Interventions. World Development. 38: 581-592.

Sadiq M.S., Singh I.P., Singh N.K., Sharma M. \& Eije O.C. (2018). Measuring Total Factor Productivity (TFP) and Unearthing the Factors Affecting TFP of Yam Farmers in Benue State of Nigeria: Harnessing the Current Untapped Agricultural Goldmine. Journal of Agriculture Allied Sciences. Vol. 7 (1). Pp. 8-21.

Simonyan J. B, Omolehin R. A, (2012). Analysis of the Impact of Fadama II Project on Beneficiary Farmers Income in Kaduna State: A Double Difference Method Approach. International Journal of Economic and Management Science, $1(11): 1-8$.

Ukoha, O.O., Okoye, B.C. \& Emetu, J (2010). Analysis of the Determinants of Total Factor Productivity among Small-Holder Cassava Farmers in Ohafia L.G.A of Abia State. Munich Personal RePEc Archive (MPRA). Paper No. 26125, Retrieved from https://mpra.ub.unimuenchen.de/26125/.

Yusuf, B.I., K.M. Baba, Mohammed, I. and S.D. Dogondaji (2009). "Determinants of Rice Production A Guide for Food Security Policy in Nigeria", In "Sustaining Agricultural Growth to Meet National Economic Development Goal". Proceedings of the 23rd Annual conference of the Farm Management Association of Nigeria, FAMAN. (Muhammed I.; Kyiogwom, U.B.; Hassan, W.A.; Ala, A.L.; Singh, A. and Dogondaji, S.D., Eds): 216. 